\title{
Pemanfaatan Seduhan Daun Ashitaba dengan Simvastatin dalam Menurunkan Kadar LDL Tikus Putih Jantan Strain Wistar
}

\author{
Theresia Ratnasari Widjaja ${ }^{1}$, Ernawati ${ }^{2 *}$ \\ Fakultas Kedokteran Universitas Wijaya Kusuma Surabaya ${ }^{1}$ \\ Bagian Farmakologi Fakultas Kedokteran Universitas Wijaya Kusuma Surabaya ${ }^{2}$ \\ *e-mail: ernawatikimura@gmail.com
}

\begin{abstract}
Abstrak
Tingginya kadar kolesterol dalam darah atau hiperkolesterolemia menjadi faktor risiko penyebab terjadinya penyakit kardiovaskuler. Salah satu intervensi yang sering dilakukan untuk mengatasi kardiovaskuler adalah pemberian obat dari golongan statin yaitu simvastatin. Selain penggunaan obat tersebut, juga dapat disertai dengan mengkonsumsi tanaman obat antara lain yaitu daun Ashitaba (Angelica keiskei). Daun ashitaba mengandung chalcones yang terbukti memiliki efek sebagai antitumor, anti-oksidan dan dapat menurunkan kadar kolesterol terutama kadar Low Density Lipopprotein (LDL) dalam darah. Penelitian ini bertujuan untuk mengetahui adanya pengaruh dari pemberian seduhan daun Ashitaba (Angelica keiskei) sebagai pendamping obat simvastatin terhadap penurunan kadar Low Density Lipoprotein (LDL) pada serum darah tikus putih jantan Strain wistar (Rattus norvegicus) yang dibuat hiperkolesterolemia. Populasi penelitian ini adalah tikus putih jantan Strain wistar (Rattus norvegicus) dengan sampel yang diambil dalam penelitian ini sebanyak 27 hewan coba tikus putih jantan. Analisis data penelitian ini menggunakan pengolahan data dengan uji statistik One Way Anova. Hasil penelitian menunjukkan bahwa seduhan daun Ashitaba yang digunakan sebagai pendamping obat simvastatin dalam menurunkan kadar LDL tikus putih jantan yang dibuat hiperkolesterolemia ternyata mampu menurunkan kadar LDL namun tidak bermakna. Hal ini terbukti dengan hasil uji Anova diperoleh nilai signifikansi atau $p$-value $=0,177$ yaitu $>$ ? $(0,05)$.
\end{abstract}

Kata Kunci: daun Ashitaba, simvastatin, kadar LDL, tikus Putih Jantan, hiperkolesterolemia

\section{Utilization of Steeping Ashitaba Leaves with Simvastatin on Lowering LDL Levels in Male White Rats Strain Wistar}

\begin{abstract}
High levels of blood cholesterol or hypercholesterolemia is an important risk factor for a cardiovascular disease. In order to overcome this problem, giving statins drug such as simvastatin is an intervention that is often applied. Besides using this drug, it can also be accompanied by consuming herbal plants which is Ashitaba leaves (Angelica keiskei). It contains Chalcones which demonstrates anti tumour property and also antioxidant activity that can lower cholesterol levels, especially $L D L$ in the blood. This study aimed to investigate the effect of Ashitaba leaves (Angelica keiskei) steeping administration in assisting simvastatin drugs to decrease the levels of Low Density Lipoprotein ( $L D L)$ in the blood serum of male white rats Strain wistar (Rattus norvegicus) with hypercholesterolemia. The population for this study was male white rats Strain wistar (Rattus norvegicus) with samples taken in this study were 27 white rats. Data analysis for this study is using One Way Anova test. The result showed that
\end{abstract}


Pemanfaatan Seduhan Daun Ashitaba dengan Simvastatin dalam Menurunkan Kadar...

Theresia Ratnasari Widjaja, Ernawati

supplementation of simvastatin treatment using steeping Ashitaba leaves might slightly reduce LDL level among male white rats Strain wistar (Rattus Norvegicus) with hypercholesterolemia. However, the result demonstrated not significant different. To assist simvastatin drugs in lowering LDL levels in male white rats Strain wistar (Rattus Norvegicus) which is made to be hypercholesterolemia can lower LDL levels slightly but not significantly ( $p$-value $=0.177)$ which is $>$ ? $(0.05)$.

Keywords: Ashitaba leaves, simvastatin, LDL levels, male white rats, hypercholesterolemia

\section{PENDAHULUAN}

Berdasarkan data Badan Kesehatan Dunia (World Health Organization, WHO) pada tahun 2015, penyakit kardiovaskular menyebabkan kematian sekitar 17,7 juta orang per tahunnya. Sekitar $31 \%$ dari kematian global disebabkan karena penyakit kardiovaskuler (WHO, 2017). Survei Sample Regristration System (SRS) pada 2014 di Indonesia menunjukkan bahwa Penyakit Jantung Koroner (PJK) menjadi penyebab kematian tertinggi pada semua umur setelah stroke, yakni sebesar 12,9\%. (Kemenkes RI, 2017). Tingginya kadar kolesterol dalam darah atau hiperkolesterolemia adalah faktor risiko penting terjadinya penyakit kardiovaskuler yang menjadi penyebab utama kematian dan kesakitan di seluruh dunia (Bantas, 2012)

Masyarakat di negara-negara
berkembang, lebih cenderung
mementingkan pekerjaan sehingga mereka
kurang memperhatikan kesehatannya dan
tidak memperhatikan makanan mereka.
Masyarakat lebih cenderung memilih

makanan yang cepat saji dan cenderung mengandung banyak kolesterol. Hal ini menyebabkan terjadinya hiperlipidemia/ hiperkolesterolemia. Kolesterol yang tinggi dapat mengendap pada dinding arteri, sehingga aliran darah di jantung, otak dan bagian tubuh lainnya dapat terhambat. Hal ini akan meningkatkan resiko seseorang terkena penyakit atherosclerosis atau penyempitan arteri, penggumpalan darah di bagian-bagian tubuh tertentu, stroke, serangan jantung, rasa sakit di dada bagian depan atau pada lengan (angina) ketika stres atau melakukan kegiatan fisik, meningkatkan resiko seseorang terkena penyakit jantung koroner (Bantas et al, 2012)

Berbagai upaya dilakukan untuk menurunkan kadar kolesterol yang tinggi untuk mencegah dan menurunkan risiko penyakit-penyakit tersebut di atas, selain itu juga dengan mengubah pola makan menjadi teratur dengan gizi seimbang, rajin berolah raga, dan mengkonsumsi obat maupun herbal. Intervensi yang sering dilakukan adalah dengan pemberian obat 
golongan statin, salah satunya simvastatin. Keunggulan simvastatin adalah pertama, simvastatin telah mempunyai sediaan generik di Indonesia, yang berarti obat lebih murah dan sudah teruji di masyarakat lebih dari 20 tahun. Kedua, menurut penelitian pada buku penyakit jantung Braunwalds, simvastatin menurunkan $20 \%$ kadar total kolesterol dan penurunan resiko penyakit pembuluh darah sebanyak 24\% dengan dosis 40mg/hari (Adesta, 2010).

Dalam menurunkan kadar kolesterol, selain penggunaan obat simvastatin, juga dapat disertai dengan mengkonsumsi tanaman obat. Tanaman obat juga sudah sering digunakan untuk mengatasi masalah-masalah kesehatan manusia, baik untuk pencegahan maupun penyembuhan suatu penyakit. Banyak keuntungan yang didapat dari tanaman obat, antara lain harganya yang terjangkau, diyakini memiliki efek samping yang ringan, mudah diolah, mudah didapat dan lain sebagainya. Salah satu tanaman yang berkhasiat dalam membantu dan mempengaruhi obat simvastatin terhadap penurunan kadar kolesterol terutama LDL dalam darah adalah daun Ashitaba (Angelica keiskei). Angelica keiskei mengandung chalcones yang terbukti memiliki efek sebagai antitumor, antioksidan, dapat menurunkan kadar LDL, kadar kolesterol dan lain sebagainya (Nagata et al, 2007). Berdasarkan informasi di atas, Penelitian ini bertujuan untuk meneliti mengenai efektivitas dari seduhan daun Ashitaba sebagai obat pendamping simvastatin dalam menurunkan kadar kolesterol terutama kadar LDL dalam serum darah tikus putih Strain wistar yang dibuat hiperkolesterol

\section{BAHAN DAN METODE}

Penelitian ini merupakan penelitian eksperimental laboratorik dengan rancangan Pre And Post Control Group Design. Hewan coba dalam penelitian ini adalah tikus putih strain wistar (Rattus norvegiccus) berjenis kelamin jantan, berat badan 100-150 gram, berumur lebih dari 2 bulan sebanyak 27 ekor dibagi menjadi 3 kelompok, yaitu: Kelompok kontrol yaitu kelompok yang hanya diberi air putih (K), Kelompok perlakuan 1 yaitu kelompok yang diberi seduhan daun asitaba (P1) dan Kelompok perlakuan 2 yaitu kelompok yang diberi seduhan daun ashitaba dan simvastatin (P2). Analisis data menggunakan uji Oneway ANOVA. Uji ini digunakan untuk membandingkan lebih dari satu kelompok.

\section{Pembuatan Seduhan Daun Ashitaba}

Daun ashitaba yang digunakan adalah daun Ashitaba kering olahan pabrik 
Pemanfaatan Seduhan Daun Ashitaba dengan Simvastatin dalam Menurunkan Kadar...

Theresia Ratnasari Widjaja, Ernawati

menjadi daun teh yang siap diseduh. Daun ashitaba kering ini terdapat dalam kemasan 100 gr yang dibeli di supermarket. Daun kering yang dijual di supermarket ini telah mengalami proses pengeringan di Trawas, Indonesia. Seduhan daun ashitaba yang digunakan dalam penelitian ini diperoleh dengan cara melarutkan atau menyeduh 1 sendok teh daun ashitaba kering dalam $50 \mathrm{ml}$ air mendidih dan dilakukan 2 kali yaitu pada pagi hari dan sore hari. Seduhan ini kemudian di bagi menjadi $1,5 \mathrm{ml}$ ke dalam setiap sonde. 1,5 $\mathrm{ml}$ seduhan daun ashitaba ini kemudian diberikan ke setiap tikus dengan cara sonde lambung, pada jam 10.00 WIB dan jam 15.00 WIB, setiap hari, selama 2 minggu (minggu ke 4 dan ke 5).

HASIL

Data terlebih dahulu dilakukan uji normalitas dengan uji kolmogorov-smirnov dengan $\alpha=0,05$. Dari uji ini didapatkan $p$ sebesar 1,000 ( $p>0,05)$, yang berarti data pengukuran LDL mempunyai distribusi normal. Selanjutnya dilakukan dengan uji homogenitas data dengan Levene's Test terhadap variabel LDL mempunyai nilai $p=$ 0,564 . Hal ini berarti varians data LDL homogen $(p>0,05)$, sehingga dapat dilanjutkan dengan uji One Way Anova.

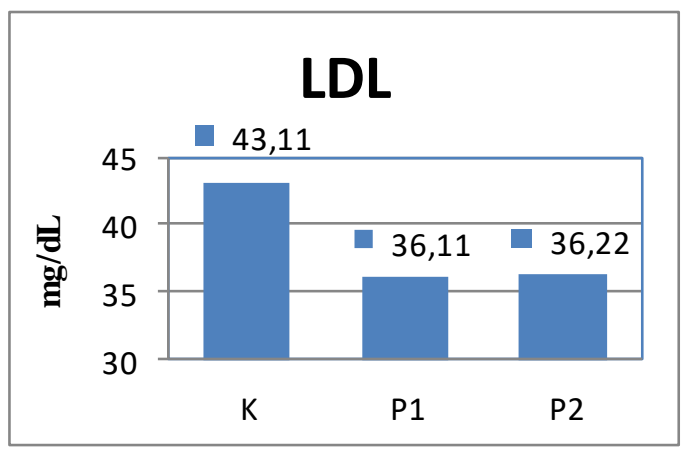

Gambar 1. Grafik Kadar LDL pada Tikus (Rattus norvegicus yang diberi seduhan daun Ashitaba pada tiap kelompok

Dari hasil kadar LDL yang didapat pada tiap kelompok, didapatkan analisis data menggunakan uji one way ANOVA pada Tabel 1.

Tabel 1. Hasil Uji One Way Anova Kadar LDL

ANOVA

LDL

\begin{tabular}{llllll}
\hline & Sum of Squares & df & Mean Square & F & Sig. \\
Between Groups & 289.407 & 2 & 144.704 & 1.864 & 0.177 \\
Within Groups & 1863.333 & 24 & 77.639 & & \\
Total & 2152.741 & 26 & & & \\
\hline
\end{tabular}

Sumber: Data Hasil Penelitian, 2016

Hasil uji One Way Anova terhadap kadar LDL pada semua kelompok perlakuan menunjukkan tidak ada perbedaan bermakna antar kelompok perlakuan dengan signifikansi $(p)$ sebesar 0,177 (p > 0,05), sehingga didapatkan kesimpulan tidak ada pengaruh Seduhan daun Ashitaba sebagai pendamping obat simvastatin 
dalam menurunkan kadar LDL tikus yang dibuat hiperkolesterolemia.

\section{PEMBAHASAN}

Hasil penelitian menunjukkan bahwa tidak ada pengaruh pemberian seduhan daun ashitaba (Angelica keiskei) sebagai pendamping obat simvastatin dalam menurunkan kadar LDL tikus putih jantan strain wistar (Rattus norvegicus) yang dibuat hiperkolesterolemia. Hal ini terbukti dengan hasil uji Anova diperoleh nilai signifikansi atau $p$-value $=0,177$ yaitu $>\alpha$ (0.05) dengan kata lain tidak ada perbedaan antar kelompok.

Hal ini diduga akibat adanya kesalahan dalam proses pemberian ashitaba, kesalahan dalam pemberian dosis ashitaba, mungkin karena proses dari bahan bakunya seperti bahan dari ashitaba yang jelek, proses pengeringan, lama penyimpanan dan proses penyeduhan. Kemungkinan lain hasil yang tidak signifikan ini kemungkinan dikarenakan ashitaba dengan simvastatin bersifat kompetitif atau saling memblok satu dengn yang lainnya.

Melalui hasil uji deskripsi menunjukkan bahwa walaupun tidak ada perbedaan yang signifikan antar kelompok, tapi tikus yang diberi perlakuan ashitaba menunjukkan terjadi penurunan LDL. Kelompok kontrol atau kelompok yang hanya diberi makan tinggi lemak mempunyai rata-rata $\mathrm{LDL}$ yang paling tinggi, yaitu sebesar 43,11 . Disusul dengan kelompok P2 sebesar 36,22 dan rata-rata LDL paling rendah terdapat pada kelompok $P 1$, yaitu sebesar 36,11.

Penurunan kadar LDL ini diduga karena adanya kandungan flavonoid pada Ashitaba yang berfungsi sebagai antioksidan. Sebagai antioksidan flavonoid bekerja secara langsung yaitu dengan mendonorkan ion hidrogen sehingga dapat menetralisir efek toksik dari adanya radikal bebas (Sumardika dan Jawi, 2012). Dalam menurunkan kadar kolesterol pada hiperkolesterolemia, flavonoid dapat menurunkan sintesis kolesterol dengan cara menghambat sintesis kolesterol yaitu dengan menghambat aktivitas enzim 3hidroksil-3-metil-glutaril-CoA (HMG-CoA) reduktase sehingga menurunkan kadar kolesterol hati (Arief et al, 2012).

Hasil penelitian menunjukkan bahwa perpaduan antara Ashitaba dan Simvastatin menghasilkan rata-rata yang lebih rendah dari pada kelompok kontrol. Keunggulan simvastatin adalah mempunyai sediaan generik di Indonesia, yang berarti obat lebih murah dan sudah teruji di masyarakat lebih dari 20 tahun; kedua, menurut penelitian pada buku penyakit jantung Braunwalds, simvastatin dapat menurunkan $20 \%$ kadar total kolesterol 
Pemanfaatan Seduhan Daun Ashitaba dengan Simvastatin dalam Menurunkan Kadar...

Theresia Ratnasari Widjaja, Ernawati

dan penurunan resiko penyakit pembuluh darah sebanyak $24 \%$ dengan dosis 40mg/hari (Adesta, 2010).

Statin menghambat sintesis hepatik dari apolipoprotein B-100, menentukan pengurangan sintesis dan sekresi lipoprotein kaya trigliserida dan peningkatan produksi reseptor untuk apolipoprotein B/E. Hal ini dapat menjelaskan mengapa atorvastatin dan simvastatin mampu mengurangi LDL pada pasien dengan hiperkolesterolemia, sehingga reseptor LDL tidak fungsional. Statin memiliki efek sederhana pada peningkatan $\mathrm{HDL}$, dan tidak ada pengaruh pada konsentrasi lipoprotein (Stancu and Sima, 2001).

\section{KESIMPULAN}

Pada penelitian ini manfaat daun Ashitaba sebagai pendamping obat simvastatin tidak terbukti dalam menurunkan kadar LDL. Hasil perbedaan kadar LDL yang tidak signifikan ini kemungkinan dikarenakan ashitaba dengan simvastatin bersifat kompetitif atau saling memblok satu sama lain.

Tidak ada perbedaan antar kelompok, namun pada nilai rata-rata LDL menunjukkan bahwa kelompok yang diberi Ashitaba dan perpaduan antara ashitaba dengan simvastatin mempunyai nilai LDL yang lebih rendah dari pada kelompok kontrol.

\section{DAFTAR PUSTAKA}

Adesta FEA, 2010. Pegaruh Pemberian Simvastation Terhadap Fungsi Memori Jangka Pendek Tikus Wistar Hiperlipidemi. Skripsi. Universitas Diponegoro, Semarang.

Arief MI, Novriansyah R, Budianto IT, Harmaji MB, 2012. Potensi Bunga Karamunting (Melastoma

Malabathricum L.) Terhadap Kadar Kolesterol Total Dan Trigliserida Pada Tikus Putih Jantan Hiperlipidemia Yang Diinduksi Propiltiourasil. Prestasi. 1(2): $118-126$

Bantas K, Agustina FMT, dan Zakiyah D, 2012. Hypercholesterolemia Risk on Workers in Industrial Estate. Jurnal Kesehatan Masyarakat Nasional. 6(5): 219-224

Kemenkes RI, 2017. Penyakit Jantung Penyebab Kematian Tertinggi, Kemenkes Ingatkan CERDIK. http://www.depkes.go.id/article/ view/17073100005/penyakitjantung-penyebab-kematiantertinggi-kemenkes-ingatkancerdik-.html 
Nagata J, Morino T, Saito M. 2007, Effects

of Dietary Angelica Keiskei on Serum and Liver Lipid Profiles, and Body Fat Accumulations in Rats. J Nutr Sci Vitaminol. 53(2): $133-137$

Stancu C and Sima A, 2001. Statins: mechanism of action and effects. J.Cell.Mol.Med. 5(4): 378-387

Sumardika IW dan Jawi IM, 2012. Ekstrak Air Daun Ubijalar Ungu Memperbaiki Profil Lipid Dan Meningkatkan Kadar SOD Darah Tikus Yang Diberi Makanan Tinggi Kolesterol. Medicina. 42(2): 67-70 WHO, 2017. Fact Sheet: Cardiovascular Diseases (CVDs). http://www.who.int/mediacentre /factsheets/fs317/en/ 